\title{
The Se-Ma-For Film Studio from 1990 to 1999
}

\author{
EWA CISZEWSKA
}

Uniwersytet Łódzki

The state-sponsored 'Se-Ma-For' Film Studio (the Polish acronym for 'Short Format Film Studio'), established in 1947, was an important element of the film industry in Łódź, as well as a major pillar of Polish animation. While Bielsko-Biała's SFR and Warsaw's Studio Miniatur Filmowych focused on cartoons, the Łódź centre specialized in the production of animated puppet films for the youngest audiences. Other Se-Ma-For projects included animated puppet films for adults, films made using special techniques such as paper-cutting or sand and salt animation, as well as short feature films by such directors as Roman Polański, Janusz Majewski, and Filip Bajon. The studio entered a period of prosperity when the national Polish television broadcaster, TVP, commissioned Se-Ma-For to make TV series for children.[1] Se-Ma-For participated in international co-productions, for example, the fifty-three-episode puppet series The Adventures of Colargol (Przygody misia Colargola, 1967-1974) was made in conjunction with the French Procidis, while The Moomins (Opowiadania Muminków), which ran from 1977 to 1982, was a Polish-Austrian co-production (in partnership with Jupiter-Film GmbH, still operating on the market today).[2]

\section{A period of change}

The 1980s were not the best time in Se-MaFor's history. Despite the glory of the 1983 Oscar

[1] A. Bańkowski, S. Grabowski, Semafor 1947-1997, “Semafor", Łódź 1999, pp. 32-33.

[2] Information on the dispute concerning the copyrights of Opowiadania Muminków can be found in: M. Bomanowska, "Dolina Muminków z łódzkiego studia filmowego", Gazeta Wyborcza, December 27, 2012.

[3] Ibid., p. 42.

[4] Interview with Krzysztof Brzozowski, May 15, 2014. Transcript available in the archives of the project (o9-Krzysztof Brzozowski). for Zbigniew Rybczyński’s Tango (1980), the studio was not able to conceal some increasingly serious problems, mainly a decrease in the number of commissions and various problems with the studio's premises. The Puppet Film Department building, located in Tuszyn near Łódź, had been in use since the beginning of the $1950 \mathrm{~s}$ and was now falling into ruin, and its renovation would require suspension of production for at least three years. Animator Henryk Ryszka still has vivid memories of the freezing bus on which Se-Ma-For employees, chilled to the marrow, commuted to Tuszyn from the city. It was a perfect symbol of their situation as "labourers of art," who had to face many adversities in the course of their work. [3] On the other hand, the distance between the city centre and the puppet animation studio created a certain artistic enclave, wherein the animators, isolated from everyday matters, could focus on their tasks. That vision of an idyllic workplace - quiet, surrounded by green areas and, most importantly, full of people who shared common goals and values - is engraved in the memories of many Se-Ma-For employees. [4]

The lamentable condition of the building in Tuszyn and the desire for a more comfortable workplace were the main reasons behind the decision in 1986 to begin construction on new facilities in the direct vicinity of the Se-MaFor office building at number 34 Pabianicka street. However, the company soon realized that it would not be able to fully finance the investment, and no government ministry was willing to cover any part of the rising costs. In 1985 the estimated value of the new site at $\mathrm{Pa}$ bianicka street, described in documents as the "Reconstruction of the Puppet Film Department," stood at PLN 105,000,000. The main financial resource for the work was a subsidy from the National Culture Development Fund. 
Construction of the shooting and prop-making rooms began in 1986, according to plan. The investment works were scheduled to be finished in 1988, but took longer than expected, and costs continued to increase - reaching, by 1989, PLN 619,000,00o. The central institutions refused to grant the studio larger subsidies, while Se-Ma-For's own PLN 8,000,000 contribution could not guarantee success. The first attempts to reduce the scope of the project were made in the early 1990s, but there was not enough money for even a limited version of the project.[5]

Finally, the investment was only partially completed (the walls were constructed, one building was roofed, and part of the heat distribution network was installed), but the only area usable for production was a connecting passage joining the building on neighbouring Browarna street to the building on Pabianicka street. Finally, with an ever-decreasing amount of commissioned work, everyone realised that there was no point in carrying on. At the same time, the maintenance costs of all the buildings had increased, and the Cinematography Committee would not agree to sell the facilities.

\section{Three days of the SONDOR}

Before 1989, the huge (by today's standards) Łódź film studios were as snug as a bug in a rug, so to say, as they were guaranteed both state-commissioned work and financing. However, at the beginning of the 1990s, the system of film financing from the Ministry of Culture's budget collapsed, and the supply of work from TVP (Se-Ma-For's main client) basically came to an end. It soon became clear to both the management (or acting management) of Se-Ma-For and its decision-making body, the Cinematography Committee, that the studio's organizational and financial structure prevented it from being competitive on the commercial services market. At that time, various - sometimes contradictory - ideas emerged about how the property and heritage of not only Se-Ma-For, but also other film institutions in Łódź should be managed.
A significant obstacle in negotiating the restructuring process of the Łódź film industry was its debt. Thus, "[...] thanks to Swiss banks' incentive, the doctrinaire désintéressement of the Cinematography Committee and regaining of statutory independence, three Łódź film studios, burdened with too much equipment that was impossible to be written off, threw themselves in at the deep end of international business," [6] as Edward Zajiček wrote. At the beginning of the 1990s, the management of the Educational Film Studio, the Feature Film Studio and the Se-Ma-For Film Studio each independently made the decision to purchase sound and editing equipment from a Swiss company, SONDOR, together with a Dolby Stereo system. This allowed them to edit $35 \mathrm{~mm}$ film with soundtracks. The equipment purchased by the studios was not identical: the Feature Film Studio purchased sound equipment, while the Educational Film Studio and Se-Ma-For chose devices based on the then-developing video technology. For Se-Ma-For, such equipment was needed for editing its TV series.

\footnotetext{
Perhaps none of [the studios] were aware that they had all, despite being allowed to do whatever they wished, not ceased to represent the Polish state. Thus, the Swiss banks could not have overlooked the fact that they were dealing with national institutions and that sooner or later they would have to demand that the Polish Ministry of Treasury pay off the loans granted to the reckless investors, along with penalty interest.[7]
}

The purchase of the equipment was supposed to make the enterprises more competitive and allow them to operate on the commercial services market. However, they soon realized that, firstly, it was still not easy to get commissions, and secondly, technological progress was moving toward gradual replacement of analogue editing with digital techniques. The

[5] National Archives in Łódź, Plany nakładów inwestycyjnych $w$ l. 1985-90, file no. 1943, folder no. 51.

[6] E. Zajiček, Poza ekranem. Polska kinematografia w latach 1896-2005, Warsaw 2009, p. 319.

[7] Ibid., p. 391. 
community, only half-jokingly, used to say that all of the work in Poland could be done on the SONDOR equipment of only one of the studios, while the equipment from all three of them was enough for the entire European market.

The decision to purchase the SONDOR equipment was fraught with consequences for all three studios. According to the parties involved, the cost was supposed to be $90 \%$ covered by the resources of Aid Funds for Poland. However, this was not the case, and as a result, none of the studios were able to pay even the first instalments. Se-Ma-For tried to negotiate with the Cinematography Committee to take responsibility for the debt, but with no result. At the same time, the debt prevented any restructuring actions.

\section{Establishing the new Semafor Film Studio}

The person who had decided on the purchase of the SONDOR equipment for Se-MaFor was their new manager, Jacek Gwizdała, a graduate of the Faculty of Management of the University of Łódź and the Faculty of Film Production Organization of the National Higher School of Film, Television and Theatre. Both the community and the employees of Se-Ma-For considered his changes to the studio's operations to be revolutionary. From then on, the studio was to be making not only short animations, but also full-length feature films and other media products, such as promotional videos, TV programmes and advertisements. Its new, broader range of activities was also reflected in a new name: The Semafor Film Studio (the hyphens would return in the name of another new company, Se-Ma-For, established in 1999 and managed by Zbigniew Żmudzki). Gwizdała’s Semafor was supposed to function in a similar way to other, more recent film studios that had been established in 1989 , by turning its various production units into independent business entities. It should be mentioned that the new business plan did

[8] Interview with Jacek Gwizdała, September 1, 2014. Transcript available in the archives of the project (37-Jacek Gwizdała). not mean that the studio would be resigning from animated projects. The new directions the studio was taking were instead an attempt to familiarize its animators with methods of working in new technological and organizational conditions. Hence, two employees - Marek Skrobecki and Mirosław Bartosik - were sent to England, to Aardman Animations as interns. The experiences from his stay in England inspired Skrobecki to make a film entitled dim., in which he animated human-sized puppets. Later, Skrobecki and Bartosik represented Semafor in helping create special effects for Schindler's List, and their work was assessed as highly professional. Their achievement was also of no small importance in the English BreakThru Films' commissioning of (the later) Se-Ma-For Film Studio to co-produce the 2008 Oscar-winning Peter and the Wolf.

According to Gwizdała, it was not easy to convince the company's one hundred-plus staff that state film financing might suddenly be cut off, and that the studio needed to start actively looking for new ways of using its employees' skills, taking into account technological progress and the new organizational conditions. Most of the team believed that things would work out somehow, and that there was no need for any radical remedial action. [8]

One idea for improving the studio's financial situation was to add film distribution to its range of services. Gwizdała obtained appropriate consent - from both the employees and the ministry - and in 1990 the company began organizing public film screenings. The decision to expand the studio's business activity was also a common-sense reaction to the deregulation of the Polish distribution system at the beginning of the 1990s, which had resulted in an almost complete lack of Semafor films on Polish screens.

Still facing problems paying off the SONDOR equipment, Gwizdała took further steps to improve the company's finances. The next idea was to establish a limited liability company in a joint venture with another company, which would have its registered office in Łódź. 
This would involve Semafor and a Swiss company, Ewimpex A.G., which would insure the transaction. The plan as negotiated would be for the Swiss party to make a contribution in kind, in the form of paying-off the SONDOR sound equipment, as well as a cash contribution of no less than CHF 150,000 (around PLN 1.6 bn, before the 1995 redenomination). On Semafor's part, a contribution in kind would be made of the building at 42 Bednarska Street, and "the necessary know-how." The newly-established company would focus on post-production services, including for films made with Ewimpex A.G. Ultimately though, the joint venture was never established, as the Works Council objected to the transaction and the various ministry bodies responsible for opinions and approvals also voiced several doubts. They questioned the legitimacy of the planned equity participation of the parties (Semafor's one-third to Ewimpex's two-thirds), as well as the handing over of the Bednarska street building to the company. Correspondence on the matter finally ended in 1992, when Jacek Gwizdała was dismissed as Studio Manager.

\section{Survival strategies}

For many of the studio's staff, the changes that had been introduced by Gwizdała had been an almost traumatic experience. Gwizdała had run the place for just two years, but in that short period of time had introduced changes that, in the employees' opinions, were too rash and therefore lacked the team's support. Ideally, his replacement would guarantee more stability and a policy that reflected the beliefs of the studio employees. Thus, Sławomir Grabowski, an editor at Se-Ma-For of many years' standing, was appointed Acting Manager. Grabowski did not see himself as an independent manager, but rather as a mediator, reconciling the employees' expectations with actions that would help the studio survive. Grabowski, as well as Andrzej Strąk, who followed him as Acting Manager from 1994 to 1999, tried not to introduce any radical changes. Instead, they focused above all on securing the employees' interests. Such cau- tious management, which characterized Semafor's business activity from 1993 to 1999, was the opposite of Gwizdała's method. The studio now tried to keep a low profile and, whenever possible, avoid making decisions.

Consecutive reports and analyses of Semafor's restructuring process led to an intense exchange of correspondence and more and more paperwork, but none of the ideas suggested were put into effect. In January 1993, the Cinematography Committee accepted The Restructuring Programme for Cinematography Units in Łódź. The document was presented to all of the Łódź film units - The Feature Film Studio, The Łódź Film Copy Production Facilities, The Educational Film Studio and Semafor, representatives of which were invited to participate in the works of the Coordination Council for the Restructuring Process. The Works Council of Semafor Film Studio replied with an official letter, in which it declined its consent for the studio's incorporation into the restructuring programme.

Semafor accused the Office of the Cinematography Committee of complete indifference to the studio's own restructuring and privatization plans. The Committee retorted by asking the studio to prepare yet another "business plan." As if that was not enough, Acting Manager of Semafor, Andrzej Strąk, and the head of the Cinematography Committee, Tadeusz Ścibor-Rylski, were apparently allergic to each other. In 1997 the studio became insolvent, and in July of that year stopped paying due social insurance contributions and property tax. In 1999, the ailing Semafor put forward its last idea - establishment of an employee-owned artistic company with TVP as its main shareholder.[9]

\section{The liquidation of Semafor}

The studio's prolonged agony ended on October 4, 1999, when the-then Head of the Cinematography Committee decided to liquidate it. Its list of creditors was long, and included

[9] National Archives in Łódź, file no. 1943. 
the SONDOR company, with which legal proceedings were still ongoing in the Swiss courts. Semafor's liabilities amounted to over seven million zloty in total, with the largest amount owed, over six million zloty, to SONDOR. In 2000 , the liquidator managed to sell the property at 42 Bednarska Street, and put the animated film-making equipment up for sale. Part of it was purchased by the Se-Ma-For limited liability company (discussed below), while the rest was sold to the Cinematography Museum. Other bits of film equipment were auctioned off later, with most purchased by the National Higher School of Film, Television and Theatre, and the Multiwizja Spółka z o.o. company, which had its registered office at 11 Łąkowa Street.

The legal status of the property in Tuszyn was still unsettled, while the auction of the building complex between Pabianicka and Browarna streets, which had been planned for March 2001, did not take place due to the auction expert's illness and a lack of funds for... advertising the auction in the national press. When the building was finally put up for sale in May, no offers were submitted. The liquidator tried to sell two plots (the tenement house at 34 Pabianicka and the production halls at $11 / 13$ Browarna Street) individually, but again met with no success. It was not until 2004 that a deal was finally closed. However, the new owner did not secure the buildings against trespassers and vandals until a full ten years later, when in the summer of 2014 they were finally fenced off.

The liquidator began putting the documentation about Semafor's films in order, which was a time-consuming task as the studio had not employed an archivist for years. Almost 1,400 folders of documents on individual films were compiled. Each contained key information, such as the credits, agreements concluded with authors, creators and film-makers, literary

[10] Information about the course of the court proceedings in the case SONDOR Willy Hungerbühler AG vs SEMAFOR examined by Swiss courts, can be found in: Information about the course of the liquidation proceedings, National Archives in Łódź, file no. 1947. and production materials, as well as dialogue and editing lists. Currently, the files, along with tapes of the films, are kept at the Łódź department of the National Film Archives at 29 Łąkowa Street. They were handed over by the liquidator as files associated with substantive copyrights. Copies were put up for sale and purchased by the National Film Archives, the Museum of Cinematography in Łódź, and the National Higher School of Film, Television and Theatre.

In the autumn of 2002, due to the impossibility of satisfying the creditors' claims (especially SONDOR's), the liquidator filed a bankruptcy petition with the court. Semafor's bankruptcy proceedings were completed in 2004, when the enterprise waived its right of perpetual usufruct on its property to the favour of the Commune of Tuszyn, and its remaining Łódź properties were sold off.

Meanwhile, proceedings in the Swiss courts between Semafor and SONDOR Willy Hungerbühler AG had continued throughout the 1990s. The liquidator's 1999 report on the lawsuits shows how tragicomic the circumstances deciding Semafor's defeat in its fight to dismiss SONDOR's claims were. According to the report, Semafor had not deposited the amount of CHF 40,000 with the Court of Cassation, because it had not received the full text of the regulation - the fax sent to Semafor by the Honorary Consulate of the Republic of Poland in Switzerland (whose address was given by Semafor as its delivery address), lacked the last page containing the deposit payment deadline. Semafor's request to reinstate the deadline so that they could pay the deposit was dismissed, which then made it impossible for the Court of Cassation to examine the complaint against the judgement of the Commercial Court.[10]

In October 2000, the liquidator notified the Office of the Cinematography Committee that he had reached an agreement with SONDOR. The Swiss company's claims were to be satisfied from the proceeds of the sale of the company's property. Even this was delated, however, by the property rights procedures. Finally, the SON- 
DOR debt was left unpaid, and in 2004 Semafor was declared bankrupt.

\section{From Semafor, back to Se-Ma-For}

Upon the liquidation of the state-owned Semafor in November 1999, a group of former employees led by Zbigniew Żmudzki, the company's production manager, established the limited liability company Se-Ma-For Film Production, in order to continue the production of animated and puppet films. The liquidator allowed the new company to take over production of The Great Journey of Doctor Mordziak (Wielka podróż doktora Mordziaka) from the Mordziaki series, and Zbigniew Lenartowicz's Lace in Knots (Sznurowadło w supełki). In December 1999, the company was registered in court and obtained the consent of the Head of the Cinematography Committee to use the name Se-Ma-For, although some members of the film-making community considered the use of the name as an unjustified claim on the heritage and decades-long tradition of the old state-owned studio. Still, others considered that Żmudzki had saved both the studio and Polish puppet film animation.

Se-Ma-For described itself as the "artistic heir" of Semafor. Despite this, a former employee of the state-owned enterprise stated bluntly that the new company "brandishes the remains" of the old company. Se-Ma-For's strategy was based on brand-building by drawing on the historic achievements of its predecessor. This was perfectly reflected in the Se-Ma-For Museum of Animation, run by the Se-Ma-For Film Foundation. The museum's website declares that visitors can "meet cult characters created by Se-Ma-For - Uszatek the Bear, Pik-Pok and Peter." [11] In other words, older characters created by the state-owned company were displayed alongside newer characters "born" in the later, private company (such as Peter from Peter and the Wolf). However, visitors are not told the story of the two Se-Ma-Fors, and the guides and exhibit descriptions (including the multimedia) do not mention the lack of legal continuity between the two, or the hyphen-less middle incarnation. This new idea of 'unity' is best expressed by a board showing film frames from various projects of both the old Semafor (including Floppy Bear [Miś Uszatek], Colargol the Bear [Miś Colargol], The Adventures of Filemon the Cat [Przygody Kota Filemona], A Few Adventures of Sparrow Tweet [Przygód kilka wróbla Ćwirka]), and the new Se-Ma-For (including The City Flows [Miasto płynie] by B. Bruszewska, Caracas by A. Błaszczyk and The Lost Tows of Świteź [Świteź] by K. Polak). Nowadays, the public knows or sees no difference between the companies. Equating the two entities is beneficial to both the studio and the city authorities, who often point to SeMa-For as an example of the continuity of Łódźs long film tradition.

Today, the largest ongoing project of the studio is the children's television series Flapper and Friends (Parauszek i przyjaciele), which has been developed from the start as a product for not only the national market, but also international audiences. The series (now consisting of 26 episodes) is co-produced by Se-Ma-For Production Switzerland, which is managed by Luc Toutounghi, a close colleague of the Polish studio. (In January 2015, when Se-Ma-For was taken over by the English company Small Screen, Toutounghi was appointed its temporary president).

\section{Summary}

The history of the state-owned Semafor Film Studio in Łódź, which existed from 1990 to 1999, reflects the problems and dilemmas of many of the companies that had to transition from state-funded cinematography to an unregulated film market. Reforms were suggested, methods of keeping the status quo were looked for, conditions of functioning were negotiated with founding/financing bodies - and still no-one was able to predict the final shape of the film market. One expert in Polish cinematography compared the situation to a slalom on a minefield made of quicksand.[12] No-one knew what part the state institutions would play in creating Polish films - whether they would carry on as

[11] http://muzeum.se-ma-for.com/o-nas-pl-4 [accessed: April 15, 2014].

[12] Zajiček, op. cit., p. 318. 
producers and organizers, or withdraw their patronage completely. Another important element of the crisis the animated film studios were facing was that TVP had also stopped investing in new children's TV series.

Another studio that did not survive those turbulent times was the Animated Film Studio in Cracow, although the Studio Miniatur Filmowych in Warsaw, the Cartoon Film Studio in Bielsko-Biała, and the Animated Film TV Studio in Poznań are all still operating. (The Cracow and Warsaw studios are currently [March 2015] undergoing transformations into cultur-

[13] B. Sobieszek, (Re)Animacja, http://www. e-kalejdoskop.pl/reanimacja.aspx, [accessed:

March 2, 2015]. al institutions). One can only speculate about what could have been if the state-run Semafor had survived just a few more years - until the Cinematography Act was passed in 2005 and the Polish Film Institute was established, which significantly improved the situation for both state-financed and commercial producers. However, it did not, and the epilogue to this history is manifested in the serious financial problems of the new Se-Ma-For, caused by incompetent handling of the subsidies granted by the Polish Film Institute. It seems that after all this time, Łódź film animation is still dealing with the same old issues.[13]

This work was supported by the Polish National Science Centre (DEC-2011/o1/B/HS2/o6123).

\section{Reżyserskie szlify. Władysław Ślesicki w Szkole Filmowej (1950-1955)}

\author{
PIOTR PŁAWUSZEWSKI
}

Uniwersytet im. Adama Mickiewicza

\section{Szkolne pisanie}

We wrześniu 1950 roku Władysław Ślesicki (urodzony 5 stycznia 1927 roku) zdał pomyślnie egzaminy wstępne do Państwowej Wyższej

[1] W tym samym roku przyjęci zostali między innymi: Andrzej Brzozowski, Sylwester Chęciński, Paweł Komorowski, Bohdan Kosiński (na wydział realizatorski); Bogusław Lambach, Zbigniew Skoczek, Jerzy Wójcik (na wydział operatorski). K. Krubski, M. Miller, Z. Turowska, W. Wiśniewski, Filmówka. Powieść o łódzkiej szkole filmowej, wyd. popr., Prószyński i S-ka, Warszawa 1998, s. $260-261$.

[2] Już wcześniej, bo w roku 1947, Władysław Ślesicki rozpoczął naukę na Uniwersytecie Warszawskim, gdzie przez rok próbował swych sił na polonistyce, by następnie przez cztery semestry studiować historię sztuki (pracując jednocześnie na stanowisku urzędniczym w Naczelnej Dyrekcji Muzeów i Ochrony Zabytków). Skąd decyzja, by podejść do egzaminów w Łodzi? Z warszawskimi klubami filmowymi i fotograficznymi oraz ama-
Szkoły Filmowej w Łodzi[1] (wydział realizatorski)[2], pisząc w tym samym czasie w kwestionariuszu rekrutacyjnym, iż film interesuje go „jako swoisty rodzaj sztuki, specjalny sposób wypowiedzi plastycznych"[3]. Przez kolejne pięć lat stykał się z materią filmową zarówno od strony stricte realizacyjnej, jak i takiej, która swój finalny kształt zyskiwała wyłącznie na papierze. Mowa tu o kilkunastu (mniej lub bardziej rozbudowanych) pracach pisemnych - szkicach scenariuszowych, analizach filmów czy konkretnych z nich postaci, opisach scen itp. Przynajmniej dwie z owych prac zasługują, by poświęcić im po latach chwilę uwagi.

$\mathrm{W}$ ramach zaliczenia jednego z przedmiotów[4] Władysław Ślesicki zobowiązany był przedstawić scenariuszowy zarys filmu fabularnego. Zaproponowaną historię opatrzył on istotnym komentarzem, podkreślającym, iż „jest ona wydarzeniem autentycznym, mającym 